\title{
New Zealand and Local Teachers' Teaching Styles in China: Perspectives of University Students on their English Language Teachers in China
}

\author{
Hua Chen ${ }^{1}$ \\ School of Foreign Languages and Literature \\ Shandong University \\ School of International Education \\ Shandong University of Finance and Economics \\ Jinan, China
}

\author{
Pascal Brown ${ }^{2 *}$ \\ The School of Linguistics and Applied Language Studies \\ Victoria University of Wellington \\ Wellington, New Zealand
}

\author{
Ying Wang ${ }^{3 *}$ \\ School of Foreign Languages and Literature \\ Shandong University \\ Jinan, China
}

\begin{abstract}
This present study investigated sixty Chinese students' perceptions of the teaching styles of New Zealand teachers and of local Chinese teachers' in an English language programme in one university in China. Questionnaires and indepth interviews were used in this study. Data analysis shows that students do not have an overall preference for either the New Zealand or local teachers. The findings indicate that both Western and local teachers may need to adjust their teaching styles to suit the needs of the students.
\end{abstract}

Keywords-teaching styles; New Zealand teachers; local Chinese teachers; students' perceptions

\section{INTRODUCTION}

An increasing number of Western tertiary institutions have been delivering their programmes in co-operative 'transnational' arrangements in mainland Chinese universities (Liu 2007). [15]Research topics in such programmes range from cultural challenges for the administrators, managers and the teaching academics (Wu 2001), [23] to teaching styles with anxiety of non-native pre-service EFL teachers (Briesmaster and Briesmaster-Paredes 2015), [4] the relationship between teaching styles and competence, self-efficacy, and commitment (González, Conde, Díaz, García, and Ricoy 2018), [9] teaching styles among academics (Zhang, Fu \& Li 2019), [25] the relationship between teaching styles and task based language teaching (TBL) (Aliasin, Saeedi, and Pineh 2019).[1]Other studies focus on teaching styles in different fields, e.g., physical education (Kolovelonis and Goudas 2012; SueSee and Barker 2019) or in language teaching (Alrajhi and Aldhafri 2015; Aliasin, Saeedi and Pineh 2019). [13][20][1][2]All these studies have contributed to the

This work was supported by The National Social Science Fund of China under Grant number 14BYY081; Shandong Humanities and Social

Sciences Research Project under Grant Number J14WD63. different perspectives of studies on teaching styles.

There has been an increase in demand for Western teachers in China, an increase in the transnational delivery of qualifications and a modernization of society. Researching teaching styles in China and the learning styles of Chinese students, can assist both the Western and local teachers. Liu (2007) studies 'communicative competence' in teaching in China and the need for teaching to be modernized. Students from China are moving out of China to study in English speaking countries [15]. Research on their learning styles in overseas contexts discusses how teachers need to better link teaching styles with learning styles of Chinese students (Wang 2009) [21].

By analyzing students' perceptions, New Zealand teachers can also continue to unravel the Chinese students' identities (Gu 2010) and learn how they best like to learn. An understanding of the students' perceptions may help both the New Zealand teachers and the local Chinese teachers prepare for their teaching and improve the communicative competence of their students in this programme, and possibly other Chinabased transnational English language programs [11].

\section{LITERATURE REVIEW}

Teaching styles are the instructional methods or the type of teaching that a teacher chooses to use in classroom. Examples are teaching where students participate in activities (studentcentred) or where the teacher lectures and the students listen passively (teacher-centred focused). A teaching style model encompasses expert, formal authority, personal model, facilitator, and delegator (Grasha 2002) and a working definition of teaching style in the present study is that 
"typified by the instructional and managerial climate that exists during the lesson and is most clearly observed in the teacher's interactions with pupils" (Siedentop 1991: 228). [2][19]

Different teaching approaches in China and in the West have created challenges in classrooms for Western teachers, for partnering local Chinese teachers and for the students themselves (Xiao 2006) [24]. The Chinese teaching style is still generally teacher-centered (Xiao 2006; Liu 2007), with the teachers responsible for providing and controlling the flow of the content and the student passively expected to absorb the content [24][15]. Xiao (2006) states that the Chinese "collectivist" culture sometimes causes a mismatch between Western teaching style and Chinese students' learning style in the face of the Western "individualist" approach to teaching and learning, and in the different perceptions of what constitutes good teaching and learning. Chinese students expressed a strong desire that Irish English teachers should prepare their lessons and teach in a more coherent, systematic, and structured way [24]. It is likely that the Irish teachers were trained in communicative language teaching strategies that include a large amount of pair and group work which may not always work with the China-based Chinese students. Rao (2002) argues that Chinese students need to adjust to the Westerners' teaching styles and the 'perceived difficulties caused by communicative language teaching (CLT) have their source in the differences between the underlying educational theories of China and those of Western countries' (p. 85) [12]. Another influence on teachers' teaching styles is their own personality, knowledge level, and experience with teaching methods, as well as their attitude and attention toward students (Xiao 2006) and these will affect students' attitudes toward and interest [24].

A related research field in understanding teaching styles appreciated by Chinese students in China, are Chinese learning styles. Watkins and Biggs (2001) formulated a theory of the Chinese learner that states that Chinese students' performance is constructed on a model of the 3 Ps (i.e. presage, process, product performance) which has the Chinese learner as a rote learner and focused on performance, such as in exams. [22]This model has been critiqued strongly by Saravanamuthu (2008) as not integrating any cultural dimension or cultural context in the way that Chinese students learn. The knowledge of a teacher about the teaching context, and indirectly their teaching style, is helped if the teacher is aware of the background of the students, and the expectations of themselves, their family and the society [18]. As Cortazzi and Jin (1996: 74) states a Chinese person's "culture of learning" is based around a whole set of expectations, attitudes, beliefs, values, perceptions, preferences, experiences, and behaviours that are characteristic of Chinese society [7]. Kennedy (2002) suggests that being 'reflective' is an important feature of Chinese learners. For them, a slow, accurate, systematic approach outweighs guessing and prediction. He believes that it is not as simple as saying that Chinese students like one style and Western students like another style [12].

A substantial body of scholarship on Chinese students' perceptions of teachers and their teaching styles exist in English language teaching. Li (2009) examined students in two New Zealand English language schools, and indicates that not all Asian student were satisfied with their teachers and learning in New Zealand. [14]The findings reveal that communicative language teaching methods adopted by New Zealand teachers are 'culturally incompatible with Asian students' learning conceptualisations (and) there exists a significant mismatch with Asian students' learning expectations" (Li 2009). [14]This mismatch is breached by the suggestion of the 'fusion method' of teaching (Bjorning-Gyde, Doogan and East 2008) which bridges the influences of the Confucian Heritage Culture and the communicative language teaching approach (East, Doogan, and Bjorning-Gyde 2007) to language teaching [3][9][8].

Against this backdrop, this present study attempts to investigate the students' perceptions in a joint transnational program between New Zealand and China on what are the preferable teaching styles.

\section{RESEARCH QUESTION AND METHODS}

One major question "What are the perceptions of the students of the teaching styles by the New Zealand and the local Chinese teachers?" guides the study.

Sixty full-time second-year undergraduate English majors of two classes at one university in China participated in the study. Participants were in the Sino-New Zealand cooperation program with 14 males and 46 females, all between 18 and 20 years of age. Data were firstly collected from a questionnaire which contained open-ended and closed questions adapted from two previous studies (Burns 2002; Cohen and Macaro 2007). [5][6]The data from the questionnaires was put into SPSS software (Version 19) and analyzed. Participants were asked to circle specific answers on the answer sheet such as the age of the teachers they prefer, New Zealander or local Chinese, and write a reason for their choice. Another three questions (the three top words to describe the local Chinese teachers' way of teaching English, the three biggest weaknesses to describe the local Chinese teachers' way of teaching English, and five suggestions on how the local based Chinese teachers could improve their teaching of English in China) asked the participants to describe the teaching styles respectively, their weaknesses and suggestions. Then thematic analysis was employed to determine the recurrent themes from the questionnaire data.

Twenty participants were recruited to participate in a focus group. The first question asked about their perceptions of the New Zealand teachers and the second was about the local Chinese teachers. It was audio-taped and transcribed into English. The goal of the focus group was to give the students an opportunity to verbalize their perceptions of the two groups of teachers. 


\section{RESEARCH FINDINGS AND DISCUSSION}

Thirty-six participants preferred a New Zealand female teacher because female teachers are 'kind' and 'more patient' than males. Twenty-seven participants prefer the New Zealand teachers to be in the age range of 26-35 stating reasons such as 'young', 'enthusiastic' and 'kind', while seventeen prefer the teachers to be in the age of 36-45 with the main reason given was teachers at this age bracket were 'experienced'. For their preference of Western or locally based teacher, fifty-five participants preferred to have a New Zealand teacher with reasons varying from being 'a native speaker' (72\%), their 'teaching style' $(25 \%)$, their 'knowledge of Western culture' $(24 \%$,$) and having 'knowledge about language' (9\%)$

The recurring words that the students used to describe their New Zealand teachers were 'lovely/kind/patient' (38\%), 'interesting' (28\%), 'humorous' (23\%) and 'strict' (25\%). For the weaknesses of the New Zealanders' teaching styles, twenty-one participants said they were 'not hardworking', thirteen said that they 'did not provide good materials' while ten said they were 'boring'. The researchers consider that the majority of participants consider that the New Zealand teachers often have the students learning communicatively in the classroom in pairs and groups. This is not always a typical teaching method used by the local Chinese teachers. The local counterpart in her own comment about teachers in China said, "generally speaking, Chinese teachers do most of the talking in class....they do not typically have many interactive activities in class and they seldom change their way of teaching" (interview, April 2009). The students may have felt that the teachers were (as one student writes) "not hard working' by putting the students in pairs and groups. This is supported by a focus group student's comment: "We like to sit in the classroom and listen and take notes more than talking in pairs".

When asked how they felt the New Zealand teachers could improve their teaching, thirty-eight participants felt that they need to teach more Western culture, thirty-three stated they needed more teaching materials and eight said they should use more listening and speaking activities.

With regard to the students' perceptions of the local Chinabased teachers, twenty-five students preferred to have a male teacher while thirty-one students preferred a female teacher, with reasons such as females are being 'more easy-going' and 'more humorous'. Forty-three would like the local Chinese teachers to be between the ages of 26 and 35 (rather than 2025 or 26-45 or older) as they felt that teachers at this age are 'experienced', 'passionate', and 'easier to communicate with than younger (i.e. 20-25 years) or older ones (45+years)'. Twenty-nine participants preferred to have a foreigner teach them rather than a local Chinese person as they felt that the overseas group knew more about culture and had a more standard pronunciation.

Recurring words or expressions such as 'considerate', 'hard-working' and 'able to understand the Chinese students easier than the New Zealand teachers' were used to describe the strengths of the local Chinese teachers. The phrases used to describe the weaknesses of the local China-based teachers' teaching style were: 'a little boring' (55\%), 'do not finish the class on time' (20\%) and 'their pronunciation' (17\%).

Suggestions from the students on how the local Chinese teachers could improve their teaching covered areas such as: 'make the classes more interesting' (38\%), 'set less homework' $(30 \%)$, 'have more speaking in class' (30\%), and 'provide more cultural information about the West and English' (20\%)

Interview data provided triangulating and qualitative insights to add to the quantitative results above. The students were very reflective about their teachers which supports Kennedy's (2002) notion of Chinese learners' being 'reflective'. Overall, students were positive for both the New Zealand and China-based teachers but with some coherent suggestions. [12]

Participants' perceptions about their comments on New Zealand teachers vary. "Because we don't have so much interest in common, maybe we can know more things about $\mathrm{NZ}$ and the NZ teachers learn something about China and that would make both of us find more things to talk about" (interview, student A) while another comment is that "I hope that the teacher could be more patient, and would like to know what students exactly need. Additionally, the teacher could be more flexible in the classroom arrangements. Lastly, humor does make a teacher more popular among students" (interview, student $\mathrm{H}$ ). These comments show that the students would like to have more communication with the New Zealand teachers because for language learners there is a need to talk with native speakers, who can at the same time learn from the students about Chinese culture. This gives direction to the curriculum writers, and the teachers for design of their classroom activities, of such a Sino-New Zealand programme to make the visiting teachers 'exchange' and 'interact' more.

The responses from the second interview question also vary. "Classes can be more active. Maybe they should tell us more things, such as culture, history and customs. We do not only want to study how to use a foreign language, but also how to use a proper expressions in a certain circumstance" (interview, student M) while another commented that: "Don't always focus on the text book and teach us more about how to appreciate English articles and some ideas of masterpieces," (interview, student Z). As was the case for the New Zealand teachers, for the Chinese teachers it appears that some professional development on teaching activities in class and ways of presenting the curriculum are needed to better match in with the students own learning needs.

Making the classes more relaxed, more lively, interactional and relevant to daily society (perhaps they are meaning local employment or study overseas opportunities) seemed to be a theme coming through the focus group. The verbatim quotes below exemplify this: "I think some Chinese teacher really need correct the pronunciation. Some new methods can make students more active. The atmosphere should be more relaxed. In fact, we can study happily. It is not necessary to make the learning so tedious, strict and nervous" (interview, student X). "They should give more time to their students and add more fresh news to their teaching. Traditional Chinese method is that teachers have the talking in class most of the time. This is 
not what the student like, but new teaching methods are needed" (interview, student Y). it thus indicates that participants desire for new teaching methods.

Overall, the data indicates that students had suggestions and reflections on ways of improving both the New Zealand and local China-based teachers' classroom teaching styles.

\section{CONCLUSION}

The findings from both the questionnaires and the focus group suggest that participants do not have an overall preference for either the New Zealand or local teachers. They are positive about the New Zealand teachers because of their humor and Western viewpoint, and positive about their local Chinese teachers for their experience, passion and hard work. Just because the New Zealand teachers are native speakers and 'experts' from overseas does not necessarily mean the Chinese learners favor them over their local teachers. In fact, the New Zealand teachers may need to adjust their communicative teaching style to include more of Chinese 'teacher directed' elements. Conversely, the local Chinese teachers may also have to adjust their teaching styles to adapt to the 'new' and changing needs of the students.

The interview data show that the students had strong opinions and suggestions on how both the groups of lecturers could improve their teaching. Examples of such suggestions are that the New Zealand teachers need to: teach more about Western culture, use current affair topics, learn Mandarin, teach more strategies of language learning, and work more on the pronunciation of the students.

The interview data also show that many English language students based in China had a negative opinion of teachercentered instruction and would prefer more communicative language teaching. Their suggestions are: make classes more active, not talk so much from the front, rely less on the course textbook, bring real workplace case studies into their teaching more, and improve their own pronunciation of English.

Another way is that teaching language communicatively by Western trained teachers is in contrast with the traditional Chinese teacher-centered and grammar-translation methodology (Wang, 2009) [21].

The research results show indirectly that this university's collaboration with the New Zealand tertiary institute is appreciated by the students. Major benefits are that they have native English-speaking teachers there at their campus in China and the NZ teachers' use of communicative teaching techniques improves the students' knowledge and confidence in using English.

\section{REFERENCES}

[1] S. H. Aliasin, Z. Saeedi, and A. J. Pineh, The relationship between EFL teachers' perception of task-based language teaching and their dominant teaching style," Cogent Education, 2019, vol. 6, pp.1-16.

[2] M. Alrajhi, and S. Aldhafri, "Academic and social self-concept: effects of teaching styles and gender in English as a foreign language setting," 2015, vol.25, pp.44-49.
[3] M. Bjorning-Gyde, F. Doogan, and M. East, "Towards a 'fusion' model for the teaching and learning of English in a Chinese context". In L. Dunn and M. Wallace (eds.). Teaching in Transnational Higher Education: Enhancing learning for offshore international students. New York: Routledge, 2008, pp.77-87.

[4] M. Briesmaster, and J. Briesmaster-Paredes, "The relationship between teaching styles and NNPSETs' anxiety levels," System, 2015, vol. 49, pp.145-156.

[5] A. Burns, Action Research in Language Teaching: Opportunities and Limitations. Sydney: Macquarie University, 2002.

[6] A. D. Cohen, and E. Macaro, Language learner strategies: 30 years of research and practice. Oxford, UK: Oxford University Press, 2007.

[7] M. Cortazzi, and L. X. Jin, "English teaching and learning in China. Language Teaching," 1996, vol.29, pp.61-80.

[8] M. East, F. Doogan, and M. Bjorning-Gyde, "Teaching English interculturally in New Zealand: Do we need a new methodological framework?" The TESOLANZ Journal, 2007, vol.15, pp.59-70.

[9] Á. González, A. Conde, P. Díaz, M. García, and C. Ricoy, "Instructors' teaching styles: relation with competence, self-efficacy, and commitment in pre-service teachers," Higher Education, 2018, vol.75, pp. 625-642.

[10] A. Grasha, Teaching with style, $2^{\text {nd }}$ ed., San Bernadino, CA: Alliance Publishers, 2002.

[11] M. M. Gu, "Identities Constructed in Difference: English Language Learners in China," Journal of Pragmatics, 2010, vol.42, pp.139-152.

[12] P. Kennedy, "Learning cultures and learning styles: mythunderstandings about adult (Hong Kong) Chinese learners". International Journal of Lifelong Education, 2002, vol.21, pp.430-445.

[13] A. Kolovelonis, and M. Goudas, "Students' recording accuracy in the reciprocal and the self-check teaching styles in physical education," 2012, vol.18, pp.733-747.

[14] B. Li, "Processed-Centered Teaching and its Implications in English Teaching in China," Journal of English Language Teaching, 2009, vol.2, pp. 24-30.

[15] J. Liu, English language teaching in China: new approaches, perspectives and standards. London: Continuum, 2007.

[16] Z. Rao, "Chinese Students' perceptions of communicative and noncommunicative activities in EFL classroom," System, 2002, vol.30, pp.85-105.

[17] N. Rao, and C.K. K. Chan, "Moving Beyond Paradoxes: Understanding Chinese Learners and Their Teachers". In Chan, C. K. K. and Rao, N. Revisiting the Chinese Learner: Changing Contexts, Changing Education. University of Hong Kong, 2009, pp.3-32.

[18] K. Saravanamuthu, "Reflecting on the Biggs-Watkins theory of the Chinese Learner," Critical Perspectives on Accounting. 2008, vol.19, pp. 138-180.

[19] D. Siedentop, Developing Teaching Skills in Physical Education. CA: Mayfield, 1991

[20] B. SueSee, and D. M. Barker, "Self-reported and observed teaching styles of Swedish physical education teachers," 2019, vol.10, pp.44-49.

[21] X. Wang, "The Process of English Language teaching and learning as experienced by teachers and students in two contexts: China and New Zealand," Unpublished. Waikato University, NZ, 2009.

[22] D. Watkins, and J. B. Biggs, "Teaching the Chinese learner: psychological and pedagogical perspectives". Comparative Education Research Centre (CERC) \& Australian Council of Educational Research (ACER), Hong Kong/Melbourne, 2001.

[23] Y. Wu, "English Language Teaching in China: Trends and Challenges," TESOL Quarterly, 2001, vol.35, pp.191-194.

[24] L. Xiao, "Bridging the Gap Between Teaching Styles and Learning Styles: A Cross-Cultural Perspective," TESL-EJ, 2006, vol.1, pp.1-15.

[25] L. F. Zhang, M. C. Fu, and D. T. Li, "Emotions and teaching styles among academics: the mediating role of research and teaching efficacy," Educational Psychology. 2019, vol.39, pp.370-394.

[26] R. Zenhui, "Matching Teaching Styles with Learning Styles in East Asian Contexts," The Internet TESL Journal, 2001, vol. VII, pp.1- 9. 